\title{
PREGNANCY AND SLEEP QUALITY
}

\author{
Nihal TASKIRAN
}

Soke Health College, University of Adnan Menderes, Aydın

\begin{abstract}
SUMMARY
Objective: We aimed in this study to measure sleep quality of pregnant women and to determine and define the affecting factors.

Material and methods: The research was conducted on 100 healthy pregnant women who applied to gynecology clinic in Research and Practice Hospital of Ahmet Necdet Sezer University. The data collected by face to face interview. "Patient Recognition Form" was used to collect information about individual socio-demographic characteristics and data about their pregnancy. Sleep quality was evaluated by using Pittsburgh Sleep Quality Index (PSQI), sleep apnea risk by Berlin Sleep Questionnaire and sleepiness by Epworth Sleepiness Scale.

Observations: $86 \%$ of the pregnant women involved in our study were found to have bad sleep quality. It was determined that sleep quality in pregnant women is in relation with age, obesity, frequency of physician visits and presence of pregnancy affecting diseases $(p<0.05)$.

Results: It is recommended to raise awareness of pregnant women about sleep and its disorders, have them visit physician regularly and develop habits for sleep hygiene.
\end{abstract}

Key words: pregnancy, sleep quality

Journal of Turkish Society of Obstetrics and Gynecology, (J Turk Soc Obstet Gynecol), 2011; Vol: 8 Issue: 3 Pages: $181-7$

\section{GEBELIK VE UYKU KALİTESI}

\section{ÖZET}

Amaç: Çalışmamızda, gebe kadınlarda uyku kalitesini ölçmeyi, gebelerin uyku kalitesini etkileyen etmenleri saptamayı ve tanımlamayı amaçladık.

Gereç ve yöntemler: Araştırma Ahmet Necdet Sezer Araştırma ve Uygulama Hastanesinde Kadın Hastalıkları ve Doğum Polikliniği’ne başvuran 100 sağlıklı gebe üzerinde yapıldı. Veriler yüz yüze görüşme yöntemi ile toplandl. Bireylerin sosyo-demografik özellikleri ve gebeliklerine ilişkin verilerini toplamak için "Hasta Tanıtım Formu” kullanıld. Uyku kalitesi Pittsburg Uyku Kalitesi İndeksi (PUKİ), uyku apne riski Berlin Uyku Anketi, uykululuk durumu Epworth Uykululuk Skalası kullanılarak değerlendirildi.

Bulgular: Çalışmamızda gebelerin \%86'sında kötü uyku kalitesi tespit edilmiştir. Uyku kalitesinin gebelerde yaş, obezite, doktora gitme sıklı̆̆l, gebeliğe etki eden hastalığın varlı̆̆ ile ilişkili olduğu saptanmıştır $(p<0.05)$.

Sonuç: Gebelerin uyku ve uyku bozuklukları konusunda bilinçlendirilmesi, kontrollere düzenli gelmelerinin sağlanması, uyku hijyenine yönelik davranışlarının geliştirilmesi önerilmektedir.

Anahtar kelimeler: gebelik, uyku kalitesi

Türk Jinekoloji ve Obstetrik Derneği Dergisi, (J Turk Soc Obstet Gynecol), 2011; Cilt: 8 Sayl: 3 Sayfa: 181- 7

Address for Correspondence: Görevlisi Nihal Taşkıran. Kadınlar Denizi mah. Sanayi karşısı Serinkent Sitesi no: 1 Kuşadası, Aydın, Turkey Phone: +90 (505) 5729899

e-mail: nihal.82@hotmail.com

Received: 14 August 2010, revised: 29 December 2010, accepted: 09 March 2011, online publication: 01 April 2011 


\section{INTRODUCTION}

Sleep is one of basic and inevitable daily activities with physiological, psychological and social dimensions which affects life quality and health of individuals $(1,2)$.

Actual definition of sleep is "the state of the organism, in which its environmental interaction is reversible, partially and periodically lost and can be revoked by various external stimuli( ${ }^{(3)}$.

Requirement for sleep varies between individuals depending on age, gender, diet, physical activity, health status and other personal factors ${ }^{(1-4)}$.

Hormonal and physical changes during pregnancy cause serious alterations on sleep and its quality. Abdominal disturbances caused by diaphragmatic pressure due to fetal development, nocturia, back pain, leg cramps, increased progesterone and estrogen levels related hormonal changes and diseases such as restless leg syndrome disarranges sleep habits and sleep quality of pregnant women ${ }^{(5-7)}$.

Although the real incidence of sleep disorders in pregnant women is unknown, it was reported to start with first trimester and reaching at its maximum level by third trimester. $97 \%$ of women in third trimester of their pregnancy have sleep disorders ${ }^{(7,8)}$.

Minimizing sleep problems and increasing sleep quality have important role in providing a healthy pregnancy period.

The aim of this research is to measure the sleep quality, determine and define its affecting factors in pregnant women who applied to gynecology clinic in Research and Practice Hospital of Ahmet Necdet Sezer University.

\section{MATERIAL AND METHODS}

The research was conducted in gynecology clinic of Research and Practice Hospital of Ahmet Necdet Sezer University.

100 healthy pregnant women inspected in clinic between November-December 2011 and those who accepted to involve were used in the study. Sleep quality and sleep points of the patients were taken as dependent variables. Socio-demographic characteristics and pregnancy related questions such as age, weight, height, neck circumference, total number of pregnancies, ranking of the current pregnancy, the type and number of abortions, curettages, stillbirths, premature births if any exist, number of children alive, week of pregnancy, education level, profession, monthly net income, social insurance membership, place lived, number of family members, smoking and alcohol intake habits, accompanying diseases, drug usage, regular drug intake and physical examination situation were taken as independent variables.

Socio-demographic Form, Pittsburgh Sleep Quality Index, Berlin Sleep Questionnaire and Epworth Sleepiness Scale were used as data collection tools.

Socio-demographic form was used for collecting data about socio-demographic characteristics and pregnancy status while questionnaire for determining sleep status and quality (PSQI) used for getting information about patients within last one month. Information about high risk, snoring, defining persistent symptom, high risk of high tension story was collected by Berlin Sleep Questionnaire which determines sleep apnea risk. Besides, Epworth Sleepiness Scale which is used to measure sleepiness situation of pregnant women provides qualitative and quantitive information about sleepiness.

Prior to the study, written consent of research centre and verbal consent of the patients involved provided after declaration of the aim of the research.

Collected data evaluated by using SPSS (version 10.0) for Windows. Frequency and percentage of categorized data declared where \pm SD average and minimummaximum values declared for numeric data. T-test and ANOVA test were used for comparing numeric data with regular distribution between groups. Numeric data with irregular distribution was compared by MannWhitney U Test and Kruskal Wallis Test. Chi square test was used to compare the frequencies between groups. Paired comparisons were made by using Duncan test. Wilcoxon Rank Test was used to compare weights before and after pregnancy. $\mathrm{p}<0.05$ was accepted as statistically significant.

\section{OBSERVATIONS}

$86 \%$ of the pregnant women involved in the study were having bad sleep quality according to Pittsburgh Sleep Quality Index. All pregnant women with good sleep quality were having total 7 hours or more sleep duration. However, only $37.2 \%$ of the pregnant women with bad sleep quality were having 7 hours or more sleep 
duration.

There was statistical significance $(p=0.025)$ between frequency of physician visit and sleep quality in pregnant women involved in the research (Table I).

Table I: Comparison of demographic characteristics by sleep quality.

\begin{tabular}{|c|c|c|c|}
\hline & $\begin{array}{l}\text { Pregnant Women } \\
\text { With Good } \\
\text { Sleep Quality } \\
(n=14)\end{array}$ & $\begin{array}{l}\text { Pregnant Wor } \\
\text { With Bad } \\
\text { Sleep Quality } \\
(n=86)\end{array}$ & \\
\hline Variables & $\mathbf{X}+\mathbf{S X}$ & $\mathbf{X}+\mathbf{S X}$ & $p=$ value \\
\hline Age (Years) & $25.07 \pm 4.91$ & $26.76 \pm 5.50$ & 0.284 \\
\hline BKI $\left(\mathrm{kg} / \mathrm{m}^{2}\right)$ & $27.69 \pm 4.42$ & $27.09 \pm 5.35$ & 0.690 \\
\hline $\begin{array}{l}\text { Neck Circumference } \\
(\mathrm{cm})\end{array}$ & $33.79 \pm 2.72$ & $34.15 \pm 2.13$ & 0.569 \\
\hline Total Number of & & & \\
\hline $\begin{array}{l}\text { Pregnancies } \\
\text { Total Number of }\end{array}$ & $2.07 \pm 1.21$ & $2.67 \pm 1.64$ & 0.226 \\
\hline $\begin{array}{l}\text { Births } \\
\text { Number of Alive }\end{array}$ & $1.75 \pm 0.89$ & $1.67 \pm 0.73$ & 0.868 \\
\hline Children & $1.50 \pm 0.53$ & $1.61 \pm 0.87$ & 0.960 \\
\hline $\begin{array}{l}\text { Week of Pregnancy } \\
\text { Number of Family }\end{array}$ & $27.71 \pm 9.25$ & $27.37 \pm 9.14$ & 0.850 \\
\hline $\begin{array}{l}\text { Members } \\
\text { Frequency of }\end{array}$ & $4.29 \pm 1.94$ & $4.24 \pm 2.15$ & 0.777 \\
\hline Physician Visits & $5.36 \pm 2.90$ & $7.93 \pm 4.24$ & 0.025 \\
\hline
\end{tabular}

T-test was used for age, BMI and Neck Circumference. Mann-White U test was used for others.

Following statistical evaluations, it was found that age of mother influences sleep quality $(\mathrm{p}=0.025) .91 .2 \%$ of the mid-aged pregnant women, ages between 29 and 45 , were having bad sleep quality. Besides, there was statistically significant difference in sleep duration and Pittsburgh Sleep Quality Global Index of those women as compared to women with other ages $(p=0.025)$. Total sleep duration of mid-aged pregnant women, ages between 29 and 45, was higher than those of younger group (Table: II).

There was a pregnancy affecting disease in $25 \%$ of the pregnant women. According to this, there was a statistically significant difference between presence of pregnancy affecting disease and sleep and daytime functional disorder ( $\mathrm{p}=0.036$ ) (Table III).

There was no statistical difference between education level, level of income, number of pregnancies and births, occupational status and pregnancy trimester according to sleep quality ( $\mathrm{p}>0.05$ ).

$28 \%$ of the pregnant women involved in the study had habitual snoring. There was statistically significant difference between week of pregnancy and habitual snoring $(\mathrm{p}=0.03) .14 .3 \%$ of these pregnants were in first trimester, $46.4 \%$ were in second and $39.3 \%$ were in third trimester. According to this result, habitual snoring is mostly observed second and third trimester. The demographic characteristics of women suffering from high and low risk sleep disorder according to Berlin Sleep Questionnaire were compared on Table IV.

Table II: Distribution of sleep quality by age depending on global score of all items in Pittsburgh Sleep Questionnaire.

\begin{tabular}{|c|c|c|c|c|}
\hline & $\begin{array}{l}\text { Ages } \\
17-23 \\
(n=30)\end{array}$ & $\begin{array}{l}\text { Ages } \\
24-28 \\
(n=36)\end{array}$ & $\begin{array}{l}\text { Ages } \\
29-45 \\
(n=34)\end{array}$ & \\
\hline Variables & $\mathbf{X}+\mathbf{S X}$ & $\mathbf{X}+\mathbf{S X}$ & $\mathbf{X}+\mathbf{S X}$ & $p=$ value \\
\hline Sleep Quality & $0.80 \pm 0.71$ & $0.92 \pm 0.91$ & $1.21 \pm 0.98$ & 0.232 \\
\hline Sleep Latency & $1.40 \pm 1.04$ & $1.28 \pm 1.06$ & $1.59 \pm 1.08$ & 0.456 \\
\hline \multicolumn{4}{|l|}{ Usual Sleep } & 0.001 \\
\hline Duration & $2.77 \pm 0.77$ & $2.42 \pm 1.20$ & $2.76 \pm 0.65$ & 0.485 \\
\hline Sleep Disorder & $1.50 \pm 0.57$ & $1.61 \pm 0.60$ & $1.76 \pm 0.65$ & 0.165 \\
\hline \multicolumn{5}{|c|}{ Daytime Functional } \\
\hline \multicolumn{5}{|l|}{ Sleeping Aid } \\
\hline Usage & $0.00 \pm 0.00$ & $0.00 \pm 0.00$ & $0.03 \pm 0.17$ & 0.379 \\
\hline Global Score & $7.87 \pm 2.79 \mathrm{ab}$ & $7.47 \pm 3.42 b$ & $9.35 \pm 2.86 \mathrm{a}$ & 0.025 \\
\hline
\end{tabular}

$a, b$ : The same letters in the same row indicates statistical significance (Duncan test, $p<0,05$ ). Mann-Whitney U Test

Average BMI (body mass index) of pregnant women with habitual snoring was $30.93 \pm 6.29 \mathrm{~kg} / \mathrm{m}^{2}$ while that of others without habitual snoring was $25.71 \pm 3.89$ $\mathrm{kg} / \mathrm{m}^{2}$. BMI of the pregnant women with habitual snoring was statistically significantly higher than those of without habitual snoring $(\mathrm{p}=0.00)$.

The average age of pregnants with habitual snoring was $29,36 \pm 6,23$ while that of others without habitual snoring was $25.42 \pm 4.68$. In our study, the relation between habitual snoring and age was significant in accordance with literature and there was habitual snoring in pregnant women with high average age $(\mathrm{p}=0.001)$.

Average neck circumference of the pregnant women with habitual snoring was $35.11 \pm 2.57$ while that of others was $33.71 \pm 1.94(<38 \mathrm{~cm}$. was accepted as normal and $>38$ as pathological). Although those measures are not risky according to the literature, the relation between neck circumference and habitual snoring of pregnants involved in the study was statistically significant $(\mathrm{p}=0.004)$. 
Table III: Distribution of sleep quality by question "is there another pregnancy influencing disease?" depending on global score of all items in Pittsburgh Sleep Questionnaire.

\begin{tabular}{llll}
\hline & $\begin{array}{l}\text { Yes } \\
(\mathbf{n}=\mathbf{2 5})\end{array}$ & $\begin{array}{l}\text { No } \\
(\mathbf{n}=\mathbf{7 5})\end{array}$ & \\
\hline Variables & $\mathbf{X}+\mathbf{X S}$ & $\mathbf{X}+\mathbf{X S}$ & $\mathbf{p}=\mathbf{v a l u e}$ \\
\hline Sleep Quality & $1.08 \pm 1.04$ & $0.95 \pm 0.84$ & 0.688 \\
Sleep Latency & $1.24 \pm 1.09$ & $1.48 \pm 1.04$ & 0.321 \\
Sleep Duration & $1.04 \pm 0.93$ & $0.84 \pm 0.92$ & 0.340 \\
Usual Sleep & & & \\
Duration & $2.76 \pm 0.83$ & $2.60 \pm 0.96$ & 0.290 \\
Sleep Disorder & $1.92 \pm 0.57$ & $1.53 \pm 0.60$ & $\mathbf{0 . 0 0 6}$ \\
Daytime Functional & & & \\
Disorder & $0.96 \pm 0.98$ & $0.56 \pm 0.87$ & $\mathbf{0 . 0 3 6}$ \\
Sleeping Aid Usage & $0.04 \pm 0.20$ & $0.00 \pm 0.00$ & 0.083 \\
Global Score & $9.04 \pm 3.42$ & $7.96 \pm 3.01$ & 0.230 \\
\hline
\end{tabular}

Mann-Whitney U test

Table IV: Comparison of demographic characteristics of women suffering from high and low risk sleep disorder according to Berlin Sleep Questionnaire. $†$

\begin{tabular}{|c|c|c|c|}
\hline & $\begin{array}{l}\text { Habitual } \\
\text { Snoring }(+) \\
(n=28)\end{array}$ & $\begin{array}{l}\text { Habitual } \\
\text { Snoring (-) } \\
(n=72)\end{array}$ & \\
\hline Variables & $\mathbf{X}+\mathbf{X S}$ & $\mathrm{X}+\mathrm{XS}$ & $p=$ value \\
\hline Age (Years) & $29.36 \pm 6.23$ & $25.42 \pm 4.68$ & 0.001 \\
\hline BKI $\left(\mathrm{kg} / \mathrm{m}^{2}\right)$ & $30.93 \pm 6.29$ & $25.71 \pm 3.89$ & 0.000 \\
\hline Neck Circumference $(\mathrm{cm})$ & $35.11 \pm 2.57$ & $33.71 \pm 1.94$ & 0.004 \\
\hline Pregnancy Ranking & $2.54 \pm 1.20$ & $2.29 \pm 1.14$ & 0.358 \\
\hline \multicolumn{4}{|l|}{ Total Number } \\
\hline of Pregnancies & $2.79 \pm 1.69$ & $2.51 \pm 1.57$ & 0.396 \\
\hline Total Number of Births & $1.79 \pm 0.71$ & $1.63 \pm 0.77$ & 0.367 \\
\hline Number of Alive Children & $1.68 \pm 0.67$ & $1.55 \pm 0.90$ & 0.210 \\
\hline Week of Pregnancy & $30.79 \pm 7.61$ & $26.11 \pm 9.35$ & 0.031 \\
\hline \multicolumn{4}{|l|}{ Number of Family } \\
\hline Members & $4.07 \pm 1.74$ & $4.32 \pm 2.24$ & 0.960 \\
\hline \multicolumn{4}{|l|}{ Frequency of Physician } \\
\hline Visits & $8.64 \pm 4.24$ & $7.15 \pm 4.09$ & 0.104 \\
\hline
\end{tabular}

†T-test was used for age, BMI and Neck Circumference. Mann-Whitney U test used for others.

Only $7 \%$ of the pregnant women involved in the study were observed for daytime sleepiness status. There was statistical significance between BMI and Epworth Sleepiness Scale of pregnant women. Comparison of demographic characteristics of women according to Epworth Sleepiness Scale was presented in Table V. Average body mass index of the pregnant women participated in our study was $31.13 \pm 7.05$ whose with Epworth Sleepiness Scale $>10$.
Table V: Comparison of demographic characteristics of women according to Epworth Sleepiness Scale $†$.

\begin{tabular}{|c|c|c|c|}
\hline & $\begin{array}{l}\text { Epworth } \\
\text { Score }<10 \\
(n=93)\end{array}$ & $\begin{array}{l}\text { Epworth } \\
\text { Score } \geq 10 \\
(n=7)\end{array}$ & \\
\hline Variables & $\mathbf{X}+\mathbf{X S}$ & $\mathbf{X}+\mathbf{X S}$ & $\mathbf{p}=$ dvalue \\
\hline Age (Years) & $26.51 \pm 5.48$ & $26.71 \pm 4.99$ & 0.922 \\
\hline BKI $\left(\mathrm{kg} / \mathrm{m}^{2}\right)$ & $26.87 \pm 4.97$ & $31.13 \pm 7.05$ & 0.036 \\
\hline Neck Circumference (cm) & $34.09 \pm 2.17$ & $34.29 \pm 2.98$ & 0.819 \\
\hline Pregnancy Ranking & $2.37 \pm 1.13$ & $2.29 \pm 1.60$ & 0.774 \\
\hline \multicolumn{4}{|l|}{ Total Number } \\
\hline of Pregnancies & $2.59 \pm 1.57$ & $2.57 \pm 2.07$ & 0.713 \\
\hline Total Number of Births & $1.65 \pm 0.72$ & $2.33 \pm 1.15$ & 0.202 \\
\hline Number of Alive Children & $\mathrm{n} 1.57 \pm 0.83$ & $2.00 \pm 1.00$ & 0.312 \\
\hline Week of Pregnancy & $27.26 \pm 9.24$ & $29.57 \pm 7.41$ & 0.690 \\
\hline \multicolumn{4}{|l|}{ Number of Family } \\
\hline Members & $4.20 \pm 2.06$ & $4.86 \pm 2.85$ & 0.573 \\
\hline \multicolumn{4}{|l|}{ Frequency of Physician } \\
\hline Visits & $7.55 \pm 4.11$ & $7.86 \pm 5.21$ & 0.984 \\
\hline
\end{tabular}

† T-test was used for age, BMI and Neck Circumference. Mann-Whitney U test used for others.

Distribution of the pregnant women with habitual snoring according to the week of pregnancy was presented on Table VI. As seen on the table, 14.3\% of 28 women with habitual snoring were in first trimester, $46.4 \%$ were in second and $39.3 \%$ were in third trimester of their pregnancies.

Table VI: Distribution of the pregnant women with habitual snoring according to the week of pregnancy.

\begin{tabular}{lll}
\hline & $\begin{array}{l}\text { Habitual Snoring } \\
(+)(\mathbf{n = 2 8})\end{array}$ & \\
\hline Week of Pregnancy & $\mathbf{n}$ & $\mathbf{\%}$ \\
\hline $1^{\text {st }}$ Trimester (weeks 0-23) & 4 & $14.3 \mathrm{a}$ \\
$2^{\text {nd }}$ Trimester (weeks 24-33) & 13 & $46.4 \mathrm{~b}$ \\
$3^{\text {rd }}$ Trimester (weeks 34-40) & 11 & $39.3 \mathrm{~b}$ \\
\hline
\end{tabular}

$a, b$ : Different letters in the same row indicates statistical significance (Chi Square)

$1^{\text {st }}$ Trimester $-2^{\text {nd }}$ Trimester $p=0.009 ; 1^{\text {st }}$ Trimester $-3^{\text {rd }}$ Trimester $p=0.035$; $2^{\text {nd }}$ Trimester $-3^{\text {rd }}$ Trimester $p=0.0589$

\section{DISCUSSION}

Pregnancy-puerperality cycle in a women's life is a period with frequent physical, mechanical, hormonal, emotional changes and new experiences. Surveys obviously exposes the relation between hormonal changes during menstrual cycle, pregnancy and menopause and sleep quality in women however, the 
number of studies which exclusively expresses that relation between hormonal levels and sleep are quite few ${ }^{(9)}$.

It is reported in one research about sleep disorders in pregnant women (Lopes et al., 2004) that pregnant women mostly complain about frequent urinating, fatigue, pelvic pressure, insomnia and lumbar pain with higher frequency of those indicated in obstetric books ${ }^{(10)} .86 \%$ of the women involved in the study were having bad sleep quality. That result is similar with those in literature.

In a research, it was reported that the total sleep duration in pregnant women are as the same as in that of nonpregnant women (average 7-7.5 hours). However, the report indicates that vigilance duration in pregnants increases due to reasons such as nocturia and physical disturbances (minimum 2-4 hours in a night). Consequently, pregnant women altered their sleeping habits in order to compensate the interruption by sleeping earlier, sleeping at weekends and snoozing(11). Total sleep duration of pregnant women with good sleep quality in our study was 7 hours or more. In spite of that, only $37.2 \%$ of the pregnant women with bad sleep quality were having 7 hours or more sleep. This situation shows that decrease in total sleep duration has adverse effects on sleep quality and pregnant women have sleep problems. This decrease in total sleep duration may be in relation with physical, mechanical and hormonal changes during pregnancy. Pregnant women express that they mostly wake up because of nocturia. This result is similar with that in literature.

There was statistical significance between physician visit frequency and sleep quality of the pregnant women involved in our research $(\mathrm{p}<0.05)$. According to this, it was observed that pregnants with bad sleep quality visits physician more frequently. This bad sleep quality was claimed to be due to lack of knowledge about course of the pregnancy, health of baby, birth and subsequently increased anxiety. However, since there is no parameter to measure anxiety level in our study, we are not able to make certain comment on this assertion.

Some researchers report that sleep quality decreases as age increases ${ }^{(1,3)}$. Hedman et al. conducted a research on pregnant women and report that changes in sleep are related to age of mother and birth weight of the baby however, sleep duration of old mothers decreased in their last pregnancy period. According to this, it is reported that total sleep duration of mothers older than 30 years old is less than 7 hours ${ }^{(5)}$. Also in our study, it was observed that age of mother affects sleep quality in accordance with literature $(\mathrm{p}=0.025)$. Mothers express that pregnancy intolerance is harder, daytime fatigue is increased thus have problems in falling asleep as the age increases. Middle aged women in our study, ages between 29 and 45, have higher total sleep duration but decreased sleep quality than those of younger ones.

Researchers report that diseases have adverse effects on sleep. Physical disturbances or pains due to diseases affects sleep quality adversely by causing results such as difficulties in falling or remaining asleep, sleep interruption in nighttime, waking up early in the morning, being sleepy whole day and fatigue ${ }^{(1,3)}$. There was a pregnancy influencing disease in $25 \%$ of pregnant women participated in our study. Also, there was a statistically significant difference between presence of a pregnancy influencing disease, sleep disorders $(p=0.006)$ and daytime functional disorders $(p=0.03)$. Pregnant women usually say that they had sleep interruptions due to pains caused by present diseases. This result is also in accordance with literature.

Respiration disorders during sleep is a public health issue causing serious subsequences such as decrease in productivity and personal performance, increase in accidents, high morbidity and mortality and decreased life quality. Changes in respiratory physiology during pregnancy due to hormonal and mechanical factors predispose women to have sleep-respiration disorders. Any situation will cause maternal hypoxia will also adversely affect sleep. The most important symptom of respiration disorders in sleep is snoring $(1,12,13)$. Mindell et al. report that one out of three pregnant women has snoring and sleep apnea is increased significantly during pregnancy thus vigilance is also increased(14). Guilleminault et al. reported that chronical and noisy snoring was $4 \%$ before pregnancy and increased significantly to $12 \%$ by the pregnancy (15). Snoring more than 5 nights a week defined as habitual( ${ }^{(16)} .28 \%$ of the pregnant women involved in our study have had habitual snoring. There was a statistical significance between week of pregnancy and habitual snoring in our research in accordance with literature $(p=0.031) .14 .3 \%$ of those pregnant women were in first trimester of their pregnancies while $46.4 \%$ 
in second and 39.3\% were in third trimester. According to that result, habitual snoring is most observed during second and third trimester. The most frequent reason of this result is increased weight.

Obesity is a risk factor for sleep related respiration disease. The ones with BMI $>29 \mathrm{~kg} / \mathrm{m}^{2}$ have 8-12 times more risk of OSAS (obstructive sleep apnea syndrome) $(10,11)$. It was reported that obese mothers with excess weight gain have frequent sleep respiration disease, apnea-hypopnea index of obese mothers (AHI: total numbers of apneas and hypopneas per hour sleep) was increased 1.7 times per hour where it was 0.2 in non-obese mothers(17). Kokten et al. (2008) reported that mothers with BMI < $30 \mathrm{~kg} / \mathrm{m}^{2}$ accepted as normal and pregnants with habitual snore had significantly higher BMI than those without habitual snore(16). In our study, pregnant women with habitual snore had significantly higher BMI than those of without habitual snore $(\mathrm{p}=0.00)$. This result is similar to that of Kokten et al.

Many researchers report that there is relation between habitual snore and age $(12,16,18)$. Sahin et al. report that average age is higher in pregnant women with habitual snore than those of without habitual snore ${ }^{(18)}$. Average age of the pregnant women with habitual snore was $29.36 \pm 6.23$ while it was $25.42 \pm 4.68$ for those without habitual snore. In our research, there was significant relation between age and habitual snore and pregnant women with higher average age had habitual snore in accordance with literature $(\mathrm{p}=0.01) .<37 \mathrm{~cm}$. and $>48$ $\mathrm{cm}$. neck circumference is defined as low and high OSAS risk in literature ${ }^{(11)}$. Sahin et al. classified that pregnant women with $<38 \mathrm{~cm}$. neck circumference as normal and $>38 \mathrm{~cm}$. as pathological and suggested that there is no relation between neck circumference and habitual snore(18). The pregnant women with habitual snore involved in our study had average $35.11 \pm 2.57$ $\mathrm{cm}$. neck circumference while the others without habitual snore is $33.71 \pm 1.94 \mathrm{~cm}$. $(<38 \mathrm{~cm}$. was accepted as normal and $>38 \mathrm{~cm}$. as pathological). Although these measures are not risky according to literature, there was statistically significant relation between neck circumference and habitual snore in pregnant women involved in the study ( $p=0.004)$.

Kapur et al. reported that Epworth Sleepiness Scale is related to respiratory sleep disorders ${ }^{(19)}$. Lopes et al. reported that daytime fatigue situation is increased by $15 \%$ in first trimester, $55 \%$ in second and $14 \%$ in third trimester ${ }^{(10)}$. Expected daytime sleepiness rate in normal population is reported to be $0.5-12 \%{ }^{(9)}$. In our study, only $7 \%$ of the pregnants had increased daytime sleepiness situation. There was statistical significance between body mass index of the pregnant women and Epworth Sleepiness Scale ( $\mathrm{p}=0.036)$.

In conclusion, $86 \%$ of the pregnant women had bad sleep quality in this study. It was determined that sleep quality of pregnant women is in relation with age, obesity, frequency of physician visits and presence of pregnancy influencing disease.

Unfortunately, there is no pharmacological and habitual research about sleep disorders during pregnancy due to their effect on fetus. Thus, sleep disorders can tried to be resolved by alternative precautions such as antacid for pyrosis, limited fluid intake for nocturia and pregnancy pillow for back pain. Moreover, treating important diseases like respiratory sleep disorders and restless leg syndrome in best time available is important. Besides, it is recommended for the pregnant women to be conscious about sleep and sleep disorders, to have regular physician visits and to develop habits for sleep hygiene.

\section{REFERENCES}

1. Kiper S.(2008). Romatoid Artritli Hastalarda Uyku Kalitesinin Değerlendirilmesi. Yüksek Lisans Tezi. Afyon Kocatepe Üniversitesi.

2. Şenel F. Uyku ve Rüya. Bilim ve Teknik Dergisi. 2005; 2: 2- 14.

3. Eryavuz N. Hemodiyaliz ve Periton Diyalizi Hastalarında Uyku Kalitesinin Karşılaştırılması. Yüksek Lisans Tezi. Afyon Kocatepe Üniversitesi 2007.

4. Bingöl N. Hemşirelerin Uyku Kalitesi, İş Doyumu Düzeyleri Arasındaki İlişkinin İncelenmesi. Yüksek Lisans Tezi. Cumhuriyet Üniversitesi 2006.

5. Hedman C, T Pohjasvaarabc, U Tolonend, A.S SuhonenMalma, V.V Myllyläa., Pohjasvaaara T., Tolonen U., A.S. Suhanen-Malm, V.V Myllyla. Effects of Pregnancy on Mothers Sleep. Sleep Medicine. 2002; 3: 37- 42.

6. Michele L.O., Mary E. Cousons-Read. Sleep Disruption During Pregnancy: 'How Does It Influence Serum Cytokines?'. Journal of Reproductive Immunology. 2007; 73: 158- 65

7. Sharma S., Franco R. Sleep and Its Diorders in Pregnancy. Wisconsin Medical Journal. 2004; 103: 48- 51.

8. Hirschman E.M. Women and Insomnia. Clinical Cornerstone. 2004; 6: 6- 17

9. Andrea Dzaja, Sara Arber, Jenny Hislop, Myriam Kerkhofs, Caroline Kopp, Thomas Pollmächer, Päivi Polo-Kantola, 
Debra J. Skene, Patricia Stenuit, Irene Tobler and Tarja Porkka. Women's Sleep in Health and Disease. Journal of Psychiatric Research 2005; 39: 55- 76.

10. Eliane Aversa Lopes; Luciane Bizari Coin de Carvalho; Priscila Bernal da Costa Seguro; Rosiane Mattar; Ademir Baptista Silva; Lucila B. Fernandes do Prado; Gilmar Fernandes do Prado. Sleep Disordered in Pregnancy. Arq Neuropsiquiatr. 2004; 62(2-a): 217- 22 .

11. Demir U.A.(2007). Obstruktif Uyku Apne Sendromu ve Obezite. Hacettepe Tip Dergisi. 2007; 38: 177- 93.

12. Sönmez S. Vardiyalı Çalışan Hemşirelerde, Horlama, uyku Bozuklukları ve İş Kazaları. Yüksek Lisans Tezi. Uludağ Üniversitesi 2006.

13. Margaret L. Moline, Lauren Broch, Rochelle Zak. Sleep in Women Across The Life Cycle From Adulthood Through Menopause. Sleep Medicine Reviews 2003.

14. Mindell JA, Jacobson BJ. Sleep disturbances during pregnancy. J Obstet Gynecol Neonatal Nurs 2000; 29: 155- 77.
15. ChiristianGullleminault, Maria-Antonia Querra-Salva, Susmita Chowdhuri, Dalva Poyares. Normal Pregnancy, Daytime Sleepiness, Snoring and Blood Pressure. Sleep Medicine. 200; 1: 289- 97.

16. Köken G., Kırşahin F., Coşar E., Saylan F., Fidan F., Yılmazer M., Ünlü M. Habitüel Horlamalı Gebelerde Serum Leptin Düzeyi. J Turk Soc Obstet Gynecol. 2008; 5: 17- 21.

17. Daniel I. Loube, J. Steven Poceta, Manuel C. Morales, Mark D. Peacock and Merrill M. Mitler. Self-Reported Snoring in Pregnancy.American College of Chest Physicians. 2006; 109: 885- 9 .

18. Şahin K. F., Köken G., Coşar E., Saylan F., Fidan F., Yılmazer M., Ünlü M. Gebelikte Uyku Apne Sendromu ve Eşlik eden Hastalıklar. Türk Jinekoloji ve Obstetrik Derneği Dergisi. 2008; $5: 22-7$

19. Kapur VK, Baldwin CM, Resnick HE, Gottlieb DJ, Nieto FJ. Sleepiness in patients with moderate to severe sleep-disordered breathing. Sleep. 2005; 28: 472- 7 